\title{
A review of the genus Gabaniella Timberlake, 1926 (Hymenoptera: Chalcidoidea: Encyrtidae) with description of a new species from Mexico
}

\author{
Обзор рода Gabaniella Timberlake, 1926 \\ (Hymenoptera: Chalcidoidea: Encyrtidae) \\ с описанием нового вида из Мексики
}

\author{
V.A. Trjapitzin \\ B.A. Тряпиџын
}

Do vostrebovania, Post Office 129344 (ulitsa Letchika Babushkina, 7), Moscow, Russia.

До востребования, п/о 129344 (ул. Лётчика Бабушкина, 7), Москва, Россия.

KEY WORDS: Hymenoptera, Encyrtidae, Gahaniella, Gahaniella akhatovi sp.n., taxonomy, biology, Mexico.

КЛЮЧЕВЫЕ СЛОВА: Нymenoptera, Encyrtidae, Gahaniella, Gahaniella akhatovi sp.n., таксономия, биология, Мексика.

ABSTRACT: Diagnosis of the New World genus Gahaniella Timberlake, 1926, key to females and males, synopsis of 6 known species with indication of their distribution and hosts and description of $G$. akhatovi sp.n. from Mexico are provided. Species of Gahaniella are endohyperparasitoids of Coccoidea (Homoptera).

PЕЗЮМЕ: В статье даны диагноз рода Gahaniella Timberlake, 1926 из Нового Света, определительная таблица видов по самкам и самцам, синопсис 6 известных видов с указанием их распространения и хозяев и описание G. akhatovi sp.n. из Мексики. Виды рода Gahaniella - вторичные внутренние паразиты кокцид (Homoptera: Coccoidea).

\section{Introduction}

Species of the genus Gahaniella are known only from North, Central and South America, Caribbean Islands, Bermuda and Hawaii. In Bermudan and Hawaiian Islands they are accidental immigrants. Presumably all of them are endohyperparasitoids of Coccoidea on different trees and shrubs, for example on such important cultivated plants as coffee tree Coffea arabica, orange Citrus sinensis, cacao tree Theobroma cacao, mango Mangifera indica and maracuya (Passiflora species with edible fruits).

The genus Gahaniella may be identified among 226 genera of Encyrtidae known from the New World using keys of Trjapitzin \& Gordh [1978a, b], Noyes [1980], Noyes et al. [1997] and Trjapitzin et al. [2008a].

In this article an abbreviation used in the text is: $\mathrm{F}$ - an antennal funicular segment.
Genus Gahaniella Timberlake, 1926

TYPE SPECIES: Gahaniella californica Timberlake, 1926, by original designation.

Timberlake, 1926: 23-31; Kerrich, 1953: 800-802; De Santis, 1964: 270-275; Sugonjaev, Trjapitzin, 1988: 183, 184.

DIAGNOSIS. Female. Body compact, not flattened dorsoventrally. Head hypognathous. Frontovertex broad, usually as long as wide. Ocelli forming a triangle with apical angle about $60^{\circ}$ or $90^{\circ}$ (or more). Toruli above level of lower eye margins (Fig. 1). Scape of antenna not expanded or inconsiderably expanded ventrally; funicle 6-segmented, its segments scarcely increasing in width from F1 to F6; clava 3-segmented, short; all segments of flagellum with longitudinal linear sensillae (Fig. 2). Mandible with one denticle and broad truncation. Formula of palpi 4:3. Pronotum short. Mesonotum $2 \mathrm{x}$ as long as wide, without parapsidal lines. Scutellum more or less convex. Wings not abbreviated, hyaline; marginal vein of the fore wing about $2 \mathrm{x}$ as long as wide; stigmal vein not longer or $1.5 \mathrm{x}$ longer than marginal; postmarginal vein not long or as long as stigmal. Spur of the middle tibia as long as the 1 st tarsal segment. Propodeum very short in the middle. Gaster subtriangular, usually as long as mesosoma. Ovipositor sheaths not or slightly exerted. General colour submetallic black, with some brilliant parts. Body length $0.92-1.75 \mathrm{~mm}$.

Male. Head thinner frontooccipitally, frontovertex broader, ocelli larger than in female. Segments of antennal funicle usually with whorls of long hairs (Fig. 3); clava solid or 2segmented. Body length 0.92-1.4 mm.

BIOLOGY. Six described species of Gahaniella and three undscribed had been reared from different Coccoidea, mainly belonging to the family Coccidae, but also to Pseudococcidae, Asterolecaniidae and Ortheziidae, frequently together with primary parasitoids from the families Encyrtidae and Aphelinidae. Hyperparasitoitism was demonstrated only for G. tertia Kerrich in Trinidad on the mealybug Planococcus citri Risso (Pseudococcidae), for G. saissetiae Timberlake in USA on the black scale Saissetia oleae Olivier (Coccidae) [data of F.D. Bennett, see: Trjapitzin et al., 2008 b], for 
Gahaniella sp. on Ceroplastes sp. in Honduras [data of F.D. Bennett, see Trjapitzin et al., 2008b], for Gahaniella sp. (now tertia) on Parasaisetia nigra Nietner in Bermuda [Simmonds, 1957; Hilburn et al., 1990], and Gahaniella sp. (apparently saissetiae) on S. oleae in Brazil. In the case of G. tertia in Trinidad the primary host is Leptomastix dactylopii Howard, 1885 (Encyrtidae). Data on immature development of Gahaniella species remain unknown to me, but I suppose that their larvae develop within larvae of primary parasitoids, as do larvae of Metablastothrix isomorpha occidentalis Voinovich, Trjapitzin et Sugonjaev, 1966 from the genus Metablastothrix Sugonjaev, 1964 related to Gahaniella.

SYSTEMATIC POSITION. According to structure of mandibles (one denticle and broad truncation) and biology Gahaniella is related to the Holarctic genus Metablastothrix. It differs from Metablastothrix in higher insertion of antennae and in some other characters. In Gahaniella, funicle of antenna is rather uniformly segmented, almost not broadening towards apex and has many longitudinal sensillae (Fig. 2); in Metablastothrix, it is broadening towards apex and has only small number of such sensillae. Trjapitzin [1973] could not place Gahaniella into his classification of the subfamily Encyrtinae, but Trjapitzin \& Gordh [1978b] referred Metablastothrix and Gahaniella to the tribe Microteryini as genera incertae sedis among subtribes of this tribe. And only Sugonjaev \& Trjapitzin [1988] referred Metablastothrix and Gahaniella to the subtribe Syrphophagina of the tribe Microteryini in the subfamily Encyrtinae. Now I accept point of view of Hayat [2006] that the tribe Microteryini Hoffer, 1955 is a synonym of the tribe Discodini Hoffer, 1955, but discussion of this problem is not a subject of the present publication.

Key to SPECIES of GAHANIELLA *

1(10) Clava of antenna 3-segmented; flagellum clavate (Fig. $2)$, with very short hairs

2(5) Fore coxae dark, with metallic luster; middle femora dark, with brown or brownish bases and apices.

3(4) Scape of antenna 3x as long as wide; F1 subquadrate, F6 a little wider than long. 1.26-1.34 mm .... G. californica

4(3) Scape of antenna a little over $4 \mathrm{x}$ as long as wide; F1 somewhat longer than wide, F6 subquadrate. 0.92 $1.33 \mathrm{~mm}$ G. saissetiae

5(2) Fore coxae and middle femora white, yellowish-white or whitish-yellow.

6(7) Scape of antenna broadened at apex (Fig. 2); pedicel 2x shorter than scape .......................................... G. tertia

7(6) Scape of antenna broadened in the middle (Fig. 4); pedicel about $3 \mathrm{x}$ shorter than scape.

8(9) Hind tibiae darkened, with yellowish-white apical 1/5 $1 / 2$ parts. Clava of antenna as long as 2 preceding funicular segments combined. Distance from toruli to mouth margin $2.5 \mathrm{x}$ more than distance from a torulus to eye margin. $1.1 \mathrm{~mm}$ G. akhatovi

9(8) Hind tibiae light (pallid), with darkened apices. Clava of antenna a little shorter than 3 preceding funicular segments combined. Distance from toruli to mouth margin $1.6 \mathrm{x}$ more than distance from a torulus to eye margin $1.75 \mathrm{~mm}$........................................... G. brasiliensis

10(1) Clava of antenna solid or 2-segmented; flagellum filiform, usually with long hairs (Fig. 2), except G. brasiliensis ................................................................ $\sigma^{7} \sigma^{7}$

11(12) Clava of antenna 2-segmented. (Scape 3x as long as

\footnotetext{
* Gahaniella incerta (Howard, 1881) is not included due to inaccessibility of material.
}

wide; F1 somewhat more $2 \mathrm{x}$ as long as wide). $1-1.32 \mathrm{~mm}$ G. californica

12(11) Clava of antenna solid.

13(14) Scape of antenna broadened at apex (Fig. 3). .......... G. tertia

14(13) Scape of antenna broadened in the middle (Fig. 1).

15(16) Funicle of antenna with short hairs, length of them less than width of segments; F1 about $3 \mathrm{x}$ as long as wide...

G. brasiliensis

16(15). Funicle of antenna with long hairs, length of them less than width of funicular segments; F1 about 1.5-2x as long as wide. 17(18). Scape of antenna about $3 \mathrm{x}$ as long as wide. $1 \mathrm{~mm}$.

G. akhatovi

18(17) Scape of antenna almost $4 \mathrm{x}$ as long as wide. (F1 somewhat over $2 \mathrm{x}$ as long as wide). $0,91 \mathrm{~mm}$...... G. saissetiae

\section{Synopsys of species}

\section{Gahaniella akhatovi Trjapitzin sp.n.} Fig. 4.

TYPE MATERIAL. Holotype $q$ - Mexico, Yucatan, Libre Union, ex Nipaecoccus nipae Maskell (Pseudococcidae) on a tree with latex, 3.IV.1990, F.D. Bennett (Zoological Institute, Russian Academy of Sciences, Sanct-Petersburg, Russia); paratypes: $1 O^{7}-$ with the same label in the same collection.

7 웅, $4 \mathrm{O}^{7} \mathrm{O}^{7}$ - from the same reared series are not included into the types due to technical reasons. They are preserved in the collection of the Antonomous University of Tamaulipas, Cd. Victoria, Mexico.

DESCRIPTION. Female (holotype and paratype). Frontovertex as long as wide, its minimum width about $3 / 7$ or $5 / 11$ of the maximum head width. Ocelli forming an obtuse triangle with apical angle more than $90^{\circ}$. Occipital margin slightly concave. Distance from toruli to mouth margin $2.5 \mathrm{x}$ more than distance to eye margin. Scape of antenna about $3 \mathrm{x}$ as long as wide, broadened in the middle (Fig. 4); pedicel 3x shorter than scape and a little longer than wide at apex (4:3); all funicular segments longer than wide; F1 as long as pedicel; clava as long as 2 preceding funicular segments combined. Scutellum as long as mesoscutum. The fore wing $2 \mathrm{x}$ as long as wide; submarginal vein thin, curved, costal cell $6 \mathrm{x}$ as long as wide; marginal vein somewhat thickend, $2 \mathrm{x}$ as long as wide; stigmal vein thin, $1.5 \mathrm{x}$ longer than marginal and forms an angle about $30^{\circ}$ with the anterior margin of wing; postmarginal vein thickened, as long as stigmal. Mesotibial spur as long as 1st segment of tarsus. Propodeum 7x shorter than scutellum (measurements in the middle). Pygostyli not far from base of gaster; lateral sides of gaster straight, converging posteriad under an angle about $60^{\circ}$. Ovipositor sheaths slightly exerted.

Body black with slight bronze luster, more intensive on dorsal side of thorax. Face and malar spaces with bronze-blue luster. Scape of antenna dark, with bronze-yellow base and apex; pedicel dark, with brownish apex; flagellum blackbrown. Mesopleura with greenish-bronze-violet-blue luster. Legs mostly whitish-yellow, including fore coxae; middle and hind coxae and hind femora black (the latter with yellowish bases and apices); hind tibiae darkened, with whitish-yellow 1/ $5-1 / 2$ apical parts; there is a weak darkening near the base of middle tibiae; last segment of all tarsi darkened.

Frontovertex and all dorsal side of thorax with microcellular sculpture. Mesopleura entirely cellular, with somewhat larger meshes, and lateral sides of propodeum with still larger meshes of sculpture. Dorsal side of thorax with dark hairs. Body length $1.1 \mathrm{~mm}$.

Male. Antennae filiform, with rather long hairs on funicle; clava solid; $3 \mathrm{x}$ as long as wide. Fore coxae somewhat darkened. Body length $1 \mathrm{~mm}$. 

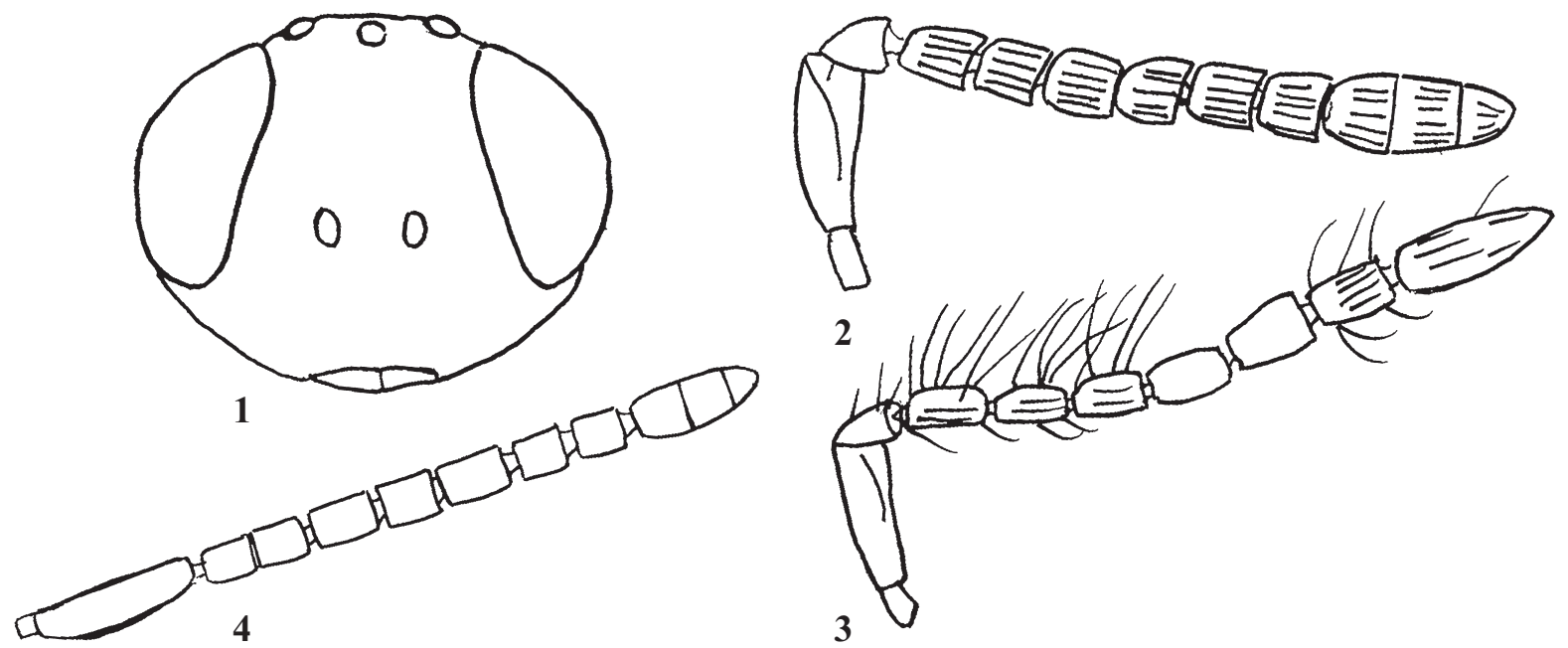

Figs 1-4. Gahaniella spp.: 1-3 - G. tertia [after Kerrich, 1953]; 1 - head of female; 2-3 - antennae, 2 - female, 3 - male (sensillae and hairs on F4-F5 not shown); $4-$ G. akhatovi sp.n., antennae of female, paratype, original (sensillae and hairs not shown).

Рис. 1-4. Gahaniella spp.: 1-3 - G. tertia [по Kerrich, 1953]; 1 - голова самки; 2-3 - усики, 2 - самка, 3 - самец (сенсиллы и волоски на F4-F5 не показаны); 4 - G. akhatovi sp.n., усики самки, паратип, оригинал (сенсиллы и волоски не показаны).

COMMENTS. Relationships of Gahaniella akhatovi sp.n. to other described species of Gahaniella is now difficult to ascertain. Its female resembles that of G. tertia (and secondary hosts of both species belong to the family Pseudococcidae), but $G$. akhatovi sp.n. differs from G. tertia in scape of antenna broadened in the middle (at apex in G. tertia). This is true also for males of these species. Differences of G. akhatovi sp.n. from other species of Gahaniella are shown in the key.

ETYMOLOGY. The new species is named after Dr. Askar Akhatov from Moscow, entomology researcher with more than 30 years experience of plant protection, who helped me cordially.

\section{Gahaniella brasiliensis (Gomes, 1941)}

Gomes, 1941: 401-402 (Coccidoxenus), 1942: 28-29 (Coccidoxenus); De Santis, 1980: 199-200 (Trichomasthus); Noyes, 1980 234 (Trichomasthus); Sugonjaev, Trjapitzin, 1988: 183, 184 [G. brasiliensis (Gomes, 1942) - date of description of the species was indicated erroneously].

NOTES. Brazil: State of Rio de Janeiro, ex Mesolecanium deltae Lizer (Coccidae), together with Metaphycus flavus (Howard, 1881), and ex Saissetia coffeae Walker (Coccidae); former Federal District.

Gahaniella californica Timberlake, 1926

Timberlake, 1926: 26-27; Kerrich, 1953: 800, 801; De Santis, 1964: 272-274; Sugonjaev, Trjapitzin, 1988: 183, 184; Trjapitzin et al., 2008a: 156.

NOTES. USA (California), ex Parthenolecanium corni Bouché (Coccidae) on Arctostaphylos sp. and ex Parthenolecanium sp., probably corni on oak Quercus californica. Mexico (Tamaulipas): ex adult female of Differococcus argentinus Morrison (Coccidae) on the American Spiny Hackberry Celtis pallida; ex material of Orthezia sp. (Ortheziidae) on dwarf pepper Capsicum annuum var. glabriscutum (in Spanish: "chile piquín"). Argentina: Prov. Salta, ex Pulvinaria argentina Leonardi (Coccidae), together with Metaphycus niger (Brèthes, 1918) and Coccophagus caridei (Brèthes, 1918); Prov. Corrientes; in Argentina G. californica had also been reared from Coccus hesperidum Linnaeus and Saissetia coffeae Walker. Uruguay, ex an undetermined soft scale (Spanish: "cocchinilla blanda") (Coccidae), together with Coccophagus caridei.
Gahaniella incerta (Howard, 1881)

Howard, 1881: 366 (Blastothrix); Peck, 1963: 423 (Blastothrix); Noyes, Woolley, 1994: 1331.

USA (Florida), ex Lecanium sp. "(Coccidae) on mesquite (Prosopis). Female unknown.

\section{Gahaniella saissetiae Timberlake, 1926.}

Timberlake, 1926: 27-28; Kerrich, 1953: 800- 801; De Santis, 1964: 274-275; Beardsley, 1976: 214; Trjapitzin, Sitdikov, 1993: 169; Browning, 1994: 70-72; Trjapitzin et al., 2004: 76.

NOTES. USA (Florida), hyperparasitoid of black scale Saissetia oleae Olivier (Coccidae); and according to F.D. Bennett [pers. comm., 1988] ex the encyrtid Microterys nietneri (Motschulsky, 1859) in a soft scale (Coccidae) on Schefflera sp. (fam. Araliaceae). Cuba, ex S. coffeae Walker on coffee tree Coffea arabica, ex Toumeyella cubensis Heidel et Köhler (Coccidae) on citruses, and ex Milviscutulus mangiferae Green (Coccidae). Caribbean Island St. Croix, ex Parasaissetia nigra Nietner. Venezuela, ex Coccus hesperidum Linnaeus. Peru, ex Ceroplastes sp. (Coccidae) on maracuya (Passiflora). Brazil, ex S. oleae on olive Olea europaea and ex Coccus viridis Green on orange Citrus sinensis. Argentina, ex Stictolecanium sp. (Coccidae). Uruguay, ex Ceroplastes sp., ex palm soft scale Eucalymnatus tessellatus Signoret (Coccidae), and ex Cerococcus sp. (Asterolecaniidae). Hawaiian Islands, an accidental immigrant found for the first time in 1960 .

\section{Gahaniella tertia Kerrich, 1953}

Kerrich, 1953: 800-802.

NOTES. Trinidad, ex Leptomastix dactylopii Howard, 1985 (Encyrtidae) - parasitoid of Planococcus citri Risso (Pseudococcidae) on cacao tree Theobroma cacao. The species was indicated also for Honduras [De Santis \& Fidalgo, 1994]. Data of Trjapitzin et al. [2008a] on discovery of G. tertia in Mexico (Yucatan) are erroneous and must be referred to G. akhatovi sp.n.

\section{Gahaniella sp.}

(apparently saissetiae Timberlake, 1926).

Compere: 1939: 89

NOTES. This species has been reared in large numbers from the black scale Saissetia oleae Olivier (Coccidae) collected in Brazil. A suspection that it is not primary parasitoid arose 
when its oviposition habits were observed. Gahaniella thoroughly explored uninfested soft scales with the ovipositor but did not deposit eggs. After the first shipments into California (USA), all Gahaniella were destroyed in quarantine room.

\section{Gahaniella sp. (non tertia).}

Simmonds, 1957: 9; Hilburn et al., 1990: 167.

NOTES. Bermuda, indicated as hyperparasitoid of Parasaissetia nigra Nietner. Most probably, an accidental immigrant.

\section{Gahaniella sp.}

Noyes et al., 1997: 205

NOTES. USA (Florida).

\section{Gahaniella sp.}

Trjapitzin et al., 2008b: 74 .

NOTES. Honduras, parasitoid of Microterys nietneri (Motschulsky, 1859) (Encyrtidae) in Ceroplastes sp. (Coccidae) on Ficus sp. [Data of F.D. Bennett, pers. comm.].

\section{Conclusions}

Information presented in this article shows that species of the genus Gahaniella are widely distributed in the warmer regions of the New World from southern USA (California and Florida) to Uruguay and northern Argentina, inclusive. Their secondary hosts range comprises usual injurious coccoids on important cultivated plants. As species of Gahaniella are hyperparasitoids (secondary parasitoids) there is a danger of accidental importation or penetration of them into other regions of the world during realization of classical biological control programs non only in nature but also in greenhouses, what is especially important for Russia. This is already proved by non-controlled penetration (ecesis) of two species of Gahaniella into Bermuda and Hawaii. In this connection, quarantine measures would be necessary. And this publication might help to identify these hyperparasitoids.

ACKNOWLEDGMENTS. I am thankful to Professor Fred D. Bennett (Isle of Man, U.K.), ex Director of the Commonwealth Institute of Biological Control (Curepe, Trinidad) for sending me some encyrtids from Mexico and for valuable information, to Professor Sergey Sergeevich Izhevsky (Moscow) for friendly help and to Dr. Serguei Vladimirovich Triapitsyn (UCR Entomological Collection, Department of Entomology, University of California, USA) for sending me necessary literature.

\section{References}

Beardsley J.W. 1976. A synopsis of the Encyrtidae of the Hawaiian Islands with keys to genera and species (Hymenoptera: Chalcidoidea) // Proceedings of the Hawaiian Entomological Society. Vol.22. No.2. P.181-228.

Browning H.W. 1994. Classical biological control of citrus scale insects // Rosen D., Bennett F.D., Capinera J.L. (eds.). Pest management in the subtropics. Biological control - a Florida perspective. Andover, U.K.: Intercept. P.49-78.

Compere H. 1939. The insect enemies of the black scale Saissetia oleae (Bern.) in South America // University of California Publications in Entomology. Vol.7. No.5. P.75-90.

De Santis L. 1964 (1963). Encírtidos de la República Argentina (Hymenoptera: Chalcidoidea) // Anales de la Comisión de Investigación Científica de la Gobernación de la Provincia de Buenos Aires. Vol.4. P.9-422.
De Santis L. 1980. Catálogo de los himenópteros brasileños serie Parasítica incluyendo Bethyloidea. Editora da Universidade Federal de Paraná (Curitiba). 395 p.

De Santis L., Fidalgo P. 1994. Catálogo de himenópteros calcidoideos // Serie de la Academía Nacional de Agronomia y Veterinaria (Buenos Aires). Vol.13. P.1-154.

Gomes J.G. 1941. Um novo parasito de Coccidae (Chalcidoidea Encyrtidae) // Boletim da Sociedade Brasileira de Agronomia. Vol.4. No.4. P.401-404.

Gomes J.G. 1942 (1941). Subsidios à sistematica dos calcidoideos brasileiros// Boletim da Escola Nacional de Agronomia (Rio de Janeiro). No.2. Art.1. P.1-44.

Hayat M. 2006. Indian Encyrtidae (Hymenoptera: Chalcidoidea). Aligarh Muslim University (published by M. Hayat). VIII +496 p.

Hilburn D.J., Marsh P.M., Schauff M.E. 1990. Hymenoptera of Bermuda// Florida Entomologist. Vol.73. No.1. P.161-176.

Howard L.O. 1881. Report of the parasites of Coccidae in the collection of this Department// In: Comstock J.H. Report of the entomologist for 1880. Report of the U.S. Department of Agriculture, 1889. P.235-373.

Kerrich G.J. 1953. Report on Encyrtidae associated with mealybugs on cacao in Trinidad and some other species related thereto // Bulletin of Entomological Research. Vol.44. Pt.4. P.789-810.

Noyes J.S. 1980. A review of the genera of Neotropical Encyrtidae (Hymenoptera: Chalcidoidea) // Bulletin of the British Museum (Natural History) (Entomology series). Vol.44. No.3. P.107-253.

Noyes J.S., Woolley J.B. 1994. North America encyrtid fauna: taxonomic changes and new taxa // Journal of Natural History. Vol.28. P.1327-1401.

Noyes J.S., Woolley J.B., Zolnerowich G. 1997. Chapter 8. Encyrtidae // Gibson G.A.P., Huber J.T., Woolley J.B. (Eds.). Annotated keys to the genera of Nearctic Chalcidoidea (Hymenoptera). NRC Research Press, Ottawa, Canada. P.170-320.

Peck O. 1963. A catalogue of the Nearctic Chalcidoidea (Insecta: Hymenoptera) // The Canadian Entomologist. Supplement 30. P.1-1092.

Simmonds F.J. 1957. A list of Coccidae of Bermuda and their parasites // Bulletin Department of Agriculture of Bermuda. No.30. P.1-12.

Sugonjaev E.S., Trjapitzin V.A. 1988. [Chalcids of the genus Metablastothrix Sugonjaev (Hymenoptera, Chalcidoidea) and peculiarities of their distribution in North America and Eurasia] // Entomologicheskoe Obozreniye. Vol.67. No.1. P.182-187 [in Russian].

Timberlake P.H. 1926. Miscellaneous new chalcid-flies of the hymenopterous family Encyrtidae // Proceedings of the U.S. National Museum. Vol.69. Art.3. No.2629. P.1-34.

Trjapitzin V.A. 1973. [Classification of parasitic Hymenoptera of the family Encyrtidae (Chalcidoidea). Part II. The subfamily Encyrtinae Walker, 1837] // Entomologicheskoe Obozreniye. Vol.52. Is.2. P.416-429 [in Russian].

Trjapitzin V.A. \& Gordh G. 1978a. [Review of genera of Nearctic Encyrtidae (Hymenoptera, Chalcidoidea). I] // Entomologicheskoe Obozreniye. Vol.57. Is.2. P.364-385 [in Russian]

Trjapitzin V.A., Gordh G. 1978b. [Review of genera of Nearctic Encyrtidae (Hymenoptera, Chalcidoidea). II] Entomologicheskoe Obozreniye. Vol.57. Is.3. P.636-653 [in Russian].

Trjapitzin V.A., Sitdikov A.A. 1993. [Description of a new species of the genus Encyrtus Latreille (Hymenoptera, Encyrtidae) from Cuba and a brief account of Cuban encyrtids] // Entomologicheskoe Obozreniye. Vol.72. Is.1. P.165-176 [in Russian].

Trjapitzin V.A., Bennett F.D., Ruíz-Cancino E., CoronadoBlanco J.M. 2004. Annotated check-list of encyrtids (Hymenoptera: Chalcidoidea: Encyrtidae) of Central America, the West Indies and Bermuda. Universidad Autonoma de Tamaulipas (Cd. Victoria, México). 207 p.

Trjapitzin V.A., Myartseva S.N., Ruíz-Cancino E., CoronadoBlanco J.M. 2008a. Clave de géneros de Encyrtidae (Hymenoptera: Chalcidoidea) de México y un catálogo de las especies // Serie avispas parasíticas de plagas y otros insectos. Universidad Autónoma de Tamaulipas (Cd. Victoria, México). No.4. P. $1-266$

Trjapitzin V.A., Myartseva S.N., Ruíz-Cancino E., CoronadoBlanco J.M. 2008b. Microterys nietneri (Motschulsky, 1859), parasitoide eficiente de Coccidae, especialmente en citricos // Serie avispas parasíticas de plagas y otros insectos. Universidad Autónoma de Tamaulipas (Cd. Victoria, México). No.5. P.1-116. 